\title{
Data and factors analysis of anti-corruption environment components of Russian public authorities
}

\author{
Olga Astafurova ${ }^{1 *}$, and Ada Golomanchuk ${ }^{2}$ \\ ${ }^{1}$ Volgograd Institute of Management - Branch of the Russian Academy of National Economy and Public Administration under the \\ President of the Russian Federation, 8 Gagarina str., Volgograd, 400066, Volgograd, Russian Federation astoa@vlgr.ranepa.ru \\ ${ }^{2}$ Volgograd Institute of Management - Branch of the Russian Academy of National Economy and Public Administration under the \\ President of the Russian Federation, 8 Gagarina str., Volgograd, 400066; Volgograd, Russian Federation. golomanchukav@mail.ru
}

\begin{abstract}
The paper is devoted to the examination of functional features of anti-corruption activities in Russian public government bodies and authorities using the cognitive modeling method . Currently, a contradictory situation is observed in corruption related assessment practice. At present, the leadership of public authorities reports on a decrease in acts of corruption whereas the statistics testify rather to the persistence of the previous level of corruption offenses than to the decline. Employees are concerned about the increasing requirements related to compliance with anti-corruption restrictions, as well as income, expenses and property obligations reporting. Citizens continue to express distrust in government bodies and state apparatus as a whole. These contradictions could be resolved if the interests of both employees of state bodies and citizens of the country are taken into account. It is assumed that when assessing anti-corruption environment effectiveness, it is advisable to take into account not only the risks of citizens, but also the risks of public officials and state authority's employees. We applied cognitive modeling as it is difficult to formalize most stages of government bodies` activities, whereas we need to take into account many factors and conflicting goals that have complex weakly structured relationships. Fishbone Diagram or Cause-andEffect-Diagram and the cognitive map were basic initial stage of cognitive modeling which allowed conducting the analysis of external and internal factors influence on the anti-corruption environment development in government bodies. The authors of the paper have shown benefits of expediency transferring of some personnel department functions into digital format.
\end{abstract}

\section{Introduction}

The performance of the existence as a system, as an integral "organism", directly depends on the orderly functioning of all its structures, which are to implement the powers of the state via its authorities. Corruption at the level of these structures disrupts the normal order of their functioning which entails disruptions in the entire state "organism" and hinders the achievement of public goals and objectives.

Necessary conditions for effective work to combat corruption have been introduced into the Russian legislation, but in order to create sufficient conditions [1] , it is necessary to activate anti-corruption enforcement in all the constituent entities of the Russian Federation.

There are some critical challenges in the development of possible transformational options in anticorruption environment in state authorities including difficulties to formalize most of its stages; uniqueness of the emerging tasks; need to take into account many factors and goals that have a complex structure of interconnection, and often contradict each other. These are weakly structured positions [2]. For these reasons, we believe that combinations of various factors to which we include personal expert experience, assessment based on it, systematized knowledge, confirmed by practice and even intuition, combined with the use of modern technologies, are the most successful for the development of a truly effective automated decisionmaking program in anti-corruption issues [3].

Cognitive analysis or cognitive modeling is an effective approach to solving poorly structured problems [4]. It is based on the concept of a cognitive map which is a directed graph which edges are assigned with weights [5]. The vertices of the cognitive map correspond to the factors or concepts which determine the situation and the horizontal edges correspond to the causal relationships between the factors [6].

In order to synthesize effective control strategies, methods of analytical processing implemented in decision support systems are applied to the cognitive map [7], aimed at studying the structure of the system and obtaining predictions of its behavior under various control actions [8].

The main advantage of the proposed apparatus of cognitive maps is the ability to systematically identify effects that can help or hinder the implementation of seemingly obvious solutions and which are difficult to

\footnotetext{
*Corresponding author: astoa@vlgr.ranepa.ru
} 
assess intuitively with a large number of factors and the variety of numerous ways of interaction between them.

The forming and using cognitive maps process includes the following procedural sequence:

- Defining a list of concepts;

- Determining the influence between each concept pair;

- Building a cognitive map;

- Stability analysis;

- System characteristics analysis on the cognitive map.

We find it most appropriate to use Silov Fuzzy Cognitive Maps as a basis for cognitive model constructing of the anti-corruption environment. This type of cognitive maps provides higher adequacy of the developed models in comparison with classical, symbolic cognitive maps, since it allows using qualitative and quantitative characteristics, taking into account several experts opinion, generating and selecting control strategies and carrying out their dynamic modeling [9].

\section{Problem Statement}

PEST and SWOT analyses of the factors influencing the processes of combating corruption in government bodies in the context of systemic transformation were applied in order to identify the main concepts.

Using PEST analysis at the beginning of the study, we examined the influence of environmental factors on anti-corruption processes in public authorities (Table 1). As a result, some main groups of factors including political, economic, social, cultural and technological were identified.

Table 1. PEST-analysis of external environment influence on anti-corruption processes in public authorities

\begin{tabular}{|c|c|c|c|}
\hline $\begin{array}{l}\text { Political } \\
\text { (P) }\end{array}$ & $\begin{array}{l}\text { Economic } \\
\text { (E) }\end{array}$ & Social (S) & $\begin{array}{l}\text { Technologi } \\
\text { cal (T) }\end{array}$ \\
\hline $\begin{array}{l}\text { Current } \\
\text { legislation } \\
\text { in the field } \\
\text { of public } \\
\text { anti- } \\
\text { corruption } \\
\text { regulation } \\
\text { Domestic } \\
\text { policy of } \\
\text { the State. } \\
\text { State } \\
\text { regulation } \\
\text { of anti- } \\
\text { corruption } \\
\text { processes. } \\
\text { Personnel } \\
\text { policy in } \\
\text { governmen } \\
\mathrm{t} \text { bodies. } \\
\text { Maintainin } \\
\mathrm{g} \\
\text { governmen }\end{array}$ & $\begin{array}{l}\text { The state of } \\
\text { national } \\
\text { economy. } \\
\text { Digitalizati } \\
\text { on of } \\
\text { economy. } \\
\text { Low level } \\
\text { of salaries } \\
\text { of } \\
\text { municipal } \\
\text { authorities. } \\
\text { Possession } \\
\text { of real } \\
\text { estate. } \\
\text { Low level } \\
\text { of } \\
\text { competitio } \\
\text { n. } \\
\text { Demand in } \\
\text { qualified } \\
\text { personnel }\end{array}$ & $\begin{array}{l}\text { Lack of } \\
\text { publicity } \\
\text { and } \\
\text { transparency } \\
\text { in decision- } \\
\text { making by } \\
\text { the } \\
\text { authorities. } \\
\text { Legal } \\
\text { under- } \\
\text { protection } \\
\text { of } \\
\text { government } \\
\text { officials. } \\
\text { Availability } \\
\text { of } \\
\text { employment } \\
\text { benefits. } \\
\text { The prestige } \\
\text { of the } \\
\text { profession. } \\
\text { Imperfect }\end{array}$ & $\begin{array}{l}\text { Redundancy } \\
\text { of state and } \\
\text { municipal } \\
\text { functions. } \\
\text { Low } \\
\text { efficiency of } \\
\text { external and } \\
\text { internal } \\
\text { control. } \\
\text { Developmen } \\
t \\
\text { innovative } \\
\text { technologies } \\
\text { in Russia } \\
\text { and } \\
\text { globally. } \\
\text { The state of } \\
\text { information } \\
\text { technology } \\
\text { in the } \\
\text { regions. }\end{array}$ \\
\hline
\end{tabular}

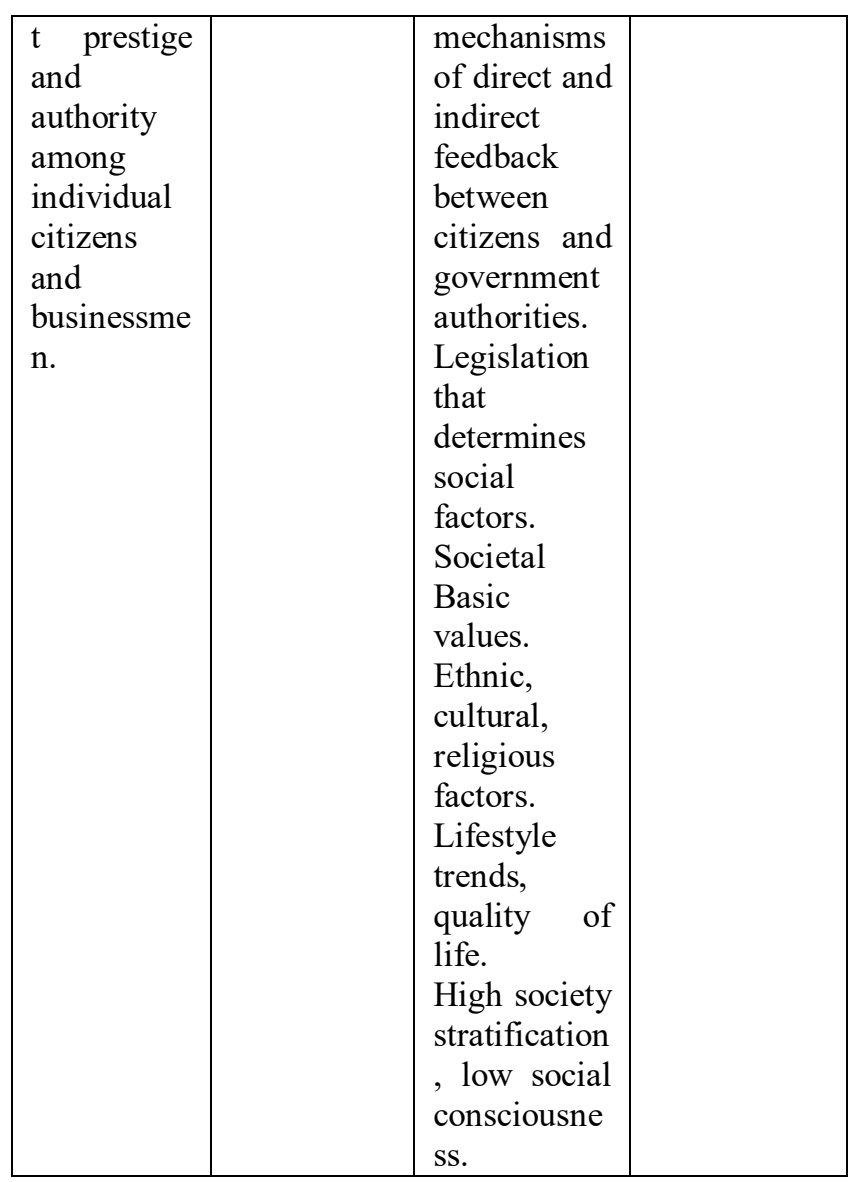

In order to draw conclusions on the analysis of the internal and external environment affecting the development of the anti-corruption environment in state authorities, a SWOT analysis was conducted. The purpose of the SWOT analysis was to identify the main factors through the systematization of available information on the strengths and weaknesses of anticorruption policies, as well as on the potential opportunities and threats from the external environment, including those related to digitalization.

A set of significant factors and conditions affecting the development of the anti-corruption environment in state authorities, obtained as a result of SWOT analysis, is given in Table 2 .

Table 2. SWOT-analysis of factors and conditions affecting anti-corruption environment development in public authorities

\begin{tabular}{|c|c|c|c|}
\hline $\begin{array}{l}\text { Strengths } \\
\text { (S) }\end{array}$ & $\begin{array}{l}\text { Weaknesses } \\
\text { (W) }\end{array}$ & $\begin{array}{l}\text { Opportunit } \\
\text { ies }(O)\end{array}$ & $\begin{array}{l}\text { Threats } \\
\text { (T) }\end{array}$ \\
\hline $\begin{array}{l}\text { Emergence } \\
\text { of new }\end{array}$ & $\begin{array}{l}\text { Underdevelo } \\
\text { ped civil }\end{array}$ & $\begin{array}{l}\text { Developme } \\
\mathrm{nt} \text { of } \mathrm{a}\end{array}$ & $\begin{array}{l}\text { Negative } \\
\text { manageme }\end{array}$ \\
\hline
\end{tabular}




\begin{tabular}{|c|c|c|c|}
\hline $\begin{array}{l}\text { forms of } \\
\text { staff } \\
\text { manageme } \\
\text { nt. } \\
\text { Informatio } \\
\text { nal and } \\
\text { analytical } \\
\text { systems } \\
\text { use for } \\
\text { corruption } \\
\text { combating. } \\
\text { Social } \\
\text { responsibil } \\
\text { ity and } \\
\text { awareness } \\
\text { increase. }\end{array}$ & $\begin{array}{l}\text { society } \\
\text { institutions. } \\
\text { Wages gap in } \\
\text { government } \\
\text { and } \\
\text { municipal } \\
\text { employees. } \\
\text { Insufficient } \\
\text { provision of } \\
\text { civil service } \\
\text { personnel } \\
\text { with the } \\
\text { necessary } \\
\text { competencies } \\
\text { in } \\
\text { information } \\
\text { and } \\
\text { communicati } \\
\text { ons } \\
\text { technologies. } \\
\text { Educational } \\
\text { institutions' } \\
\text { activities are } \\
\text { not } \\
\text { sufficiently } \\
\text { coordinated } \\
\text { with the } \\
\text { government } \\
\text { bodies } \\
\text { needs. } \\
\text { Low level of } \\
\text { remuneration. } \\
\text { Negative } \\
\text { social and } \\
\text { psychological } \\
\text { factors: poor } \\
\text { socialization, } \\
\text { unstable life } \\
\text { position, the } \\
\text { decline in the } \\
\text { prestige of } \\
\text { civil servant } \\
\text { profession. }\end{array}$ & $\begin{array}{l}\text { system of } \\
\text { anti- } \\
\text { corruption } \\
\text { activities. } \\
\text { Reduction } \\
\text { of acts of a } \\
\text { corruption } \\
\text { orientation } \\
\text { due to } \\
\text { increased } \\
\text { awareness } \\
\text { of employees } \\
\text { emp the } \\
\text { and formation of } \\
\text { an } \\
\text { appropriate } \\
\text { attitude } \\
\text { towards the } \\
\text { facts of } \\
\text { corruption. } \\
\text { Improving } \\
\text { the activities } \\
\text { of personnel } \\
\text { departments } \\
\text { Maintaining } \\
\text { social } \\
\text { stability. }\end{array}$ & $\begin{array}{l}\text { nt } \\
\text { tendencies } \\
\text { Migration } \\
\text { of } \\
\text { qualified } \\
\text { personnel } \\
\text { outside } \\
\text { the } \\
\text { regions. } \\
\text { Laying off } \\
\text { workers } \\
\text { and } \\
\text { reducing } \\
\text { the } \\
\text { number of } \\
\text { jobs in } \\
\text { personnel } \\
\text { departmen } \\
\text { ts. } \\
\text { Changing } \\
\text { family } \\
\text { traditions. }\end{array}$ \\
\hline
\end{tabular}

As a result, we identified three groups of factors:

- a number of factors consistent with the initial data on anti-corruption environment [10] (employees involved in corruption liability, data on noncompliance with existing regulations, data on HR department services for anti-corruption work, social and psychological factors, etc.);

- a number of factors reflecting a positive impact on anti-corruption environment [11] (transparency, revealed facts of corruption, educational work of experts and HR services, etc.);

- a number of factors characterizing the main destabilizing effects on the anti-corruption environment (corruption offenses, corruption crimes, training of specialists without taking into account the competencies in organizing personnel work to combat corruption, lack of civil servants with sufficient informational and communicational skills, etc.).

\section{Research Questions}

The authors clarified the list of basic concepts and determined cause-and-effect relationships between them which were achieved through the use of the Fishbone Diagram (or Cause and Effect Diagram or Ishikawa diagram). The diagram displays all the factors influencing the problem under consideration. The complex application of the above methods (approaches) allows one to get the greatest effect when building a cognitive model of the influence of the main external and internal factors on the transformation of the anticorruption environment in government bodies.

Further analysis of the factors influencing the transformation of the anti-corruption environment in state authorities under the influence of the internal and external environment was carried out using the Fishbone Diagram (Figure 1).

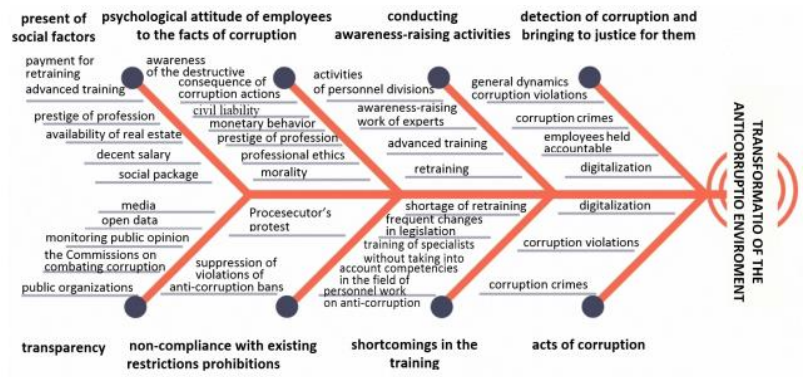

Figure 1. Fishbone Diagram of anti-corruption environment transformation in state authorities and government bodies.

The factors of the 1st order in their turn are influenced by smaller bones which include such factors as:

Admissible acts of a corrupt nature are the corruption offenses result [12]; corruption crimes; digitalization which in turn depends on information and communication technologies development (ICT), the development of digital employee competencies are of the 3 rd order factors. Besides, the factors of the 3rd order influencing corruption offenses are administrative, material and disciplinary responsibility.

The factors "revealing corruption facts and bringing responsibility for them" include the following influence: the general dynamics of corruption offenses, corruptionrelated crimes, bringing to responsibility employees (federal civil servants, civil servants, municipal employees, employees holding municipal positions, other officials) and digitalization. The "digitalization" factor as well as development of information and communication technologies (ICT), the development of digital competencies of employees is of the 3rd order [13].

The "awareness-raising work on anti-corruption activities is influenced by educational work of experts explaining typical situations; the activities of personnel departments, the workload of employees of these departments with routine processes (filling in magazines, 
assigning and conducting testing, analyzing test results ...) can be automated. These functions will be assumed by the information and analytical system developed under the Russian Foundation for Basic Research grant "Formation of the Anti-Corruption Environment in State and Municipal Authorities by introducing information and analytical system "Methods and tactics of combating corruption for state and municipal employees" [14].

Deficiencies in personnel training are the result of training specialists without taking into account competencies in the field of organizing personnel work to combat corruption [15]; shortcomings in retraining, untimely passing of advanced training, as well as frequent changes in legislation.

Official statistics on corruption offenses of various departments are very diverse and contain numerous indicators in the reporting forms. Sufficiently deep knowledge of statistics and mathematics is required to be able to operate with these indicators. In addition to criminal law information on corruption, knowledge in the field of criminology, psychology, sociology, economics, political science, and other branches of knowledge related to the study of crime is required. Unfortunately, the state educational standards on jurisprudence do not provide as compulsory those disciplines which knowledge is so necessary for professionals to study criminal or judicial statistics and combating crime [16].

Non-compliance with existing restrictions and regulations is influenced by prosecutor protest of the; presentation of the prosecutor; suppression of violations of anti-corruption prohibitions [17];

Psychological attitude of employees to the facts of corruption depends on civic responsibility; prestige of the profession; morality, moral principles, personal qualities and individual motivation. This factor can be influenced by explaining the basics of monetary behavior and professional ethics. The employee must be aware of the destructive consequences of acts of corruption.

Transparency is influenced by the media; the need to upload open data to appropriate information systems; public organizations; anti-corruption commissions; public opinion monitoring.

Changes in social factors are facilitated by decent wages; affordable real estate; available social employment benefits which include payment for medical services, gym or swimming pool subscription, free meals, etc.; further education, retraining or advanced training covered by the employer; occupational prestige.

\section{Purpose of the Study}

The purpose of data and factors analysis of the anticorruption environment components of state authorities and government bodies determine mutual influencing indicators in a systematic study of theoretical and practical problems arising in the course of this process and determining their solution perspective.

The object of inquiry is social relations that develop in the course of individual components formation of the anti-corruption environment of state authorities and government bodies.

The subject being analyzed is Russian legislation norms in the field of combating corruption and modern technologies for the formation of individual components of anti-corruption environment of state authorities and government bodies..

\section{Research Methods}

In the course of the study, we applied various methods including the universal scientific method of historical materialism; general scientific methods of cognition (comparison, ascent from the abstract to the concrete, analysis, synthesis, induction, deduction, generalization, classification and abstraction), partially scientific methods (formal legal, comparative legal, method of interpreting legal norms, dogmatic method), interdisciplinary method of formalization.

\section{Findings}

The results of trends analysis served as the basis for identifying the cognitive map concepts that have the greatest impact on the anti-corruption environment of state authorities and government bodies. The structure of the cognitive map is presented in Figure 2.

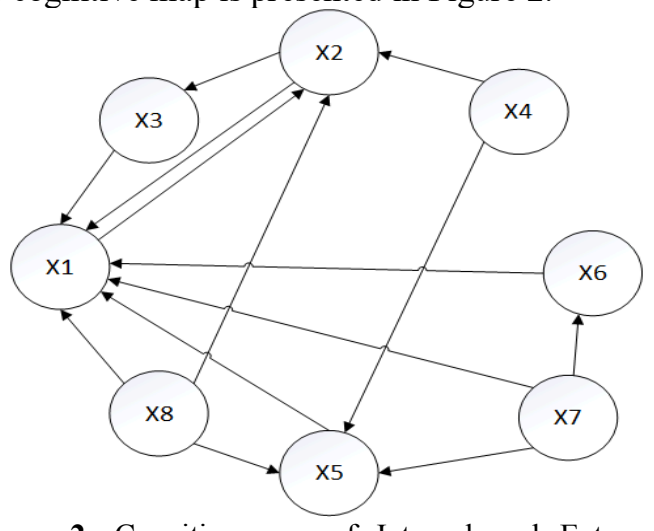

Figure 2. Cognitive map of Internal and External factor influencing anti-corruption environment of state authorities and government bodies

As the first and second concepts we defined X1 which is the Index of Admissible Corruption Offense and X2 which is the Index of Corruption Facts Revealing; these two indices have a mutual influence on each other. In addition, we identified the Social Index $\mathrm{X} 3$ which is in turn affects the Index of Admissible Corruption Offense.

Transparency Index $\mathrm{X} 4$ is the fourth index that influences the Index of Corruption Facts Revealing and the Index of Psychological Attitude of Employees to corruption facts (X5). The index of the psychological attitude of employees to Corruption Facts affects the Index of Permitted Corruption Offenses.

The sixth index is the Personnel Training Index X6 which also affects the Index of Admissible Corruption Offense.

The seventh index is the Anti-Corruption Education is X7 which affects the Index of Admissible Corruption 
Offense, the Index of the Psychological Attitude of Employees to corruption facts and the Index of Personnel Training.

The eighth index $\mathrm{X} 8$ is the Index of Existing Restrictions and Prohibitions which influences the Index of Admissible Corruption Offense, the Index of Employees Brought to Justice for Corruption offenses and the Index of the Psychological Attitude of Employees to the Corruption Facts.

The mutual influence of the concepts on each other and on the problem under consideration at the initial stage of the study was determined primarily by experts, but the further development of the model involves the construction of econometric relationships.

Practical outcomes can be used for cognitive modeling of possible scenarios for anti-corruption environment development in government bodies.

This model is scalable, that is it makes it possible to detail large factors into smaller components. The factors were grouped to map the model and determine the interrelationships of the model. The connections between factors show their influence as one-sided (a change in one factor leads to a change in another), mutual (both factors affect each other), as well as the influence of a factor on itself (a change in a factor at a previous moment leads to its change at a later moment). If the influence is direct (the growth of the initial factor leads to an increase in the associated factor), then the relationship is considered positive, if the opposite influence (the growth of the factor leads to a decrease in the associated factor), then the relationship is negative. Links in the model diagram appear as influence arrows. An important quantity for creating a model is the bond strength. The value characterizes the intensity of influence of one factor on another.

\section{Conclusion}

The anti-corruption system consists of many different elements, including measures and means of preventing and combating corruption.

The aim of the study is to identify the complex effect of external and internal factors influencing and conditioning the development of anti-corruption environment in government bodies, namely by reducing uncertainty in predicting personnel shortage with the necessary up-to-date work skills and qualifications; determining possible scenarios for anti-corruption environment development; identification of necessary retraining and advanced training programmes. The paper presents the results of the cognitive modeling first steps, namely the construction of a cognitive map of mutual influencing concepts and factors which have an overall impact on the problem under consideration. The assessment of each concept importance is conducted at the first stage of cognitive map structure formation. Assigning connections between concepts (factors) can be made in the form of values (terms) of a linguistic variable (weak; strong; very strong) or in numerical form in accordance with the approximate value of the connection strength between the concepts.

\section{Acknowledgment}

The study has been carried out with the financial support of the Russian Foundation for Basic Research within the framework of the Research project No. 18-29-16119 "Formation of the anti-corruption environment in the state and municipal authorities through the introduction of the information and analytical system 'Methods and tactics of countering corruption for state and municipal employees'".

\section{References}

1. C. Baez-Camargo, P. Bukuluki, R. Sambaiga, African Studies 79 (2), 232-249 (2020)

2. Z.K. Avdeeva, S.V. Kovriga, D.I. Makarenko, Large Systems Management 16, 26-39 (2007)

3. E.V. Golomanchuk, O.A. Astafurova, D.A. Mehrabyan, Business. Education. Law 3 (52), 309316 (2020) doi: 10.25683 / volbi.2020.52.378.

4. S.M. Brown, Journal of Management Studies 29, 287-307 (1992)

5. W.R. Zhang, S. Chen, R.S. King, IEEE Transactions on Systems, Man and Cybernetics 22, 103-113 (1992)

6. Yu.G. Fedulov, A.B. Yusov, Social Policy: Formalization, Measurement, Forecasting, 384 (Direct Media, Moscow, 2015)

7. C.D. Stylios, P. Groumpos, Journal of Intelligent \& Fuzzy systems 8 (2), 83-98 (2000)

8. M.Yu. Mizulin, G. Fedulov, A.B. Yunusov, Application of Systems Theory to Politics and Economics: monograph, 312 (Moscow, RASS, 2011)

9. O.A. Astafurova, A.S. Borisova, A.V. Golomanchuk, T.A. Omelchenko, International Journal of Information and Education Technology 10 (2), 90-94 (2020) https://doi: 10.18178/ijiet.2020.10.2.1345.

10. H. Kim, International Journal of Urban and Regional Research 45 (22), 1057-1071 (2020)

11. C.L. Atkinson, International Journal of Public Administration 43 (13), 1169-1182 (2020)

12. A. Castro, N. Phillips, S. Ansari, Academy of Management Annals 14 (2), 935-968 (2020)

13. K. Veeramani, S. Jaganathan, Ksii Transactions on Internet and Information Systems 14 (9), 36933711 (2020)

14. K.-H. Yu, S-D. Kang, C. Rhodes, Business \& Society 59 (7), 1377-1409 (2020)

15. V. Vukovic, Journal of Comparative Economics 48 (1), 124-143 (2020)

16. V.I. Shulga, Bulletin of the Vladivostok State University of Economics and Service 1 (28), 28-33 (2015)

17. Z.Q Wang, Advances in Education Research 85, 101-103 (2015) 